Agnieszka Kisztelińska-Węgrzyńska

Łódź

\title{
AUSTRIA W DYPLOMACJI POLSKIEJ PO 2004 ROKU
}

Republika Austriacka to ważny niemieckojęzyczny partner polityczny Polski. Oczywiście nie tak istotny jak Republika Federalna Niemiec, jednakże nadal bliższy politycznie i gospodarczo niż pozostałe państwa niemieckiego obszaru językowego. Polska dyplomacja zabiega w widoczny sposób o utrwalenie poprawnych warunków współpracy z państwami Europy Zachodniej. Priorytety polskiego resortu spraw zagranicznych koncentrowały się w pierwszych latach XXI wieku na przystąpieniu Polski do struktur europejskich. Po wejściu naszego państwa do Unii Europejskiej na nowo wyznaczono kierunki działań politycznych i dyplomatycznych na najbliższe lata ${ }^{1}$. Celem poniższej analizy jest próba odpowiedzi na pytanie o miejsce Austrii w dyplomacji polskiej po rozszerzeniu UE w 2004 roku. Na ile relacje polsko-austriackie zmieniły się w tym czasie, co miało wpływ na powyższe zmiany i jak przebiegały stosunki dwustronne w latach 2004-2011.

W świetle dotychczasowych badań nad współczesnymi relacjami polsko-austriackimi można stwierdzić, że poprawne stosunki polityczne zawiązane jeszcze podczas zimnej wojny kontynuowano po 1989 roku. Wielokrotne spotkania na najwyższym szczeblu i korzystne umowy gospodarcze wzmacniały wymianę handlową. Według byłego ambasadora polskiego w Republice Austriackiej prof. Władysława Bartoszewskiego różnice jakie wystąpiły pomiędzy Polską i Austrią podczas jesieni ludów nie miały negatywnego wpływu na wzajemne postrzeganie polityczne i społeczne. Polacy byli pozytywnie odbierani nad Dunajem, a potencjał gospodarczy jakim dysponowali dzięki gospodarce wolnorynkowej

${ }^{1}$ W. Bartoszewski, Ustrój a polityka zagraniczna, „Polski Przegląd Dyplomatyczny"2001, nr 1, s. 15-26, W. Bartoszewski, Współdecydować w Europie, „Więźz" 2001, nr 2, s. 74-86, D. Kornacka, Zagraniczne inwestycje bezpośrednie a dyfuzja technologii, „Przegląd Organizacji" 2000, nr 10, s. 15-18. 
stał się dla Austrii atrakcyjnym zapleczem². Zrozumiałe było jednak i to, że z różnych względów zainteresowania polityczne Wiednia rozdzieliły się na cały obszar Europy Wschodniej, także na południe. Wzmacnia tą tezę austriacki publicysta i historyk Andreas Stadler piszący o „zapomnianej przyjaźni” polsko-austriackiej i ",krytycznym” okresie w tych stosunkach, czyli latach 1999-2001³. Austria negatywnie oceniała rozszerzenie UE na Wschód i zmniejszyła widocznie wymianę handlową z Polską. Słynny wówczas „,bojkot” naddunajskiej republiki znalazł wiele miejsca w polskiej publicystyce ${ }^{4}$. Brak było ważnych wizyt i politycznych spotkań. Wzmocniono natomiast wymianę kulturalną, stypendialną i naukową. Prężne Forum Polsko-Austriackie skupiło osoby zainteresowane wzajemną promocją obydwu państw w przed dzień rozszerzenia UE. Efekty tej pracy przyniosły wymierne korzyści w następnych latach ${ }^{5}$.

Bazą najnowszych stosunków polsko-austriackich są traktaty państwowe podpisane w okresie PRL ${ }^{6}$. Po wejściu Polski do UE zawarto tylko jedną umowę dwustronną. Dotyczyła opodatkowania w zakresie podatków od dochodu i majątku. Dokument wszedł w życie 1 IV 2005 roku i wywołał wiele kontrowersji. W publikacjach „Gazety Prawnej” i „Gazety Wyborczej” oceniono go krytycznie, zwracając uwagę, że jest niekorzystny dla obywateli polskich. W praktyce zdarzają się sytuacje, kiedy na podstawie własnych przepisów wewnętrznych zarówno Polska jak i Austria uznają, że obywatele polscy są rezydentami podatkowymi w jednym jak i drugim kraju. W takich przypadkach swoich praw należy dochodzić w oparciu o postanowienia Umowy między Polską i Austrią w sprawie unikania podwójnego opodatkowania w zakresie podatków od dochodu i od majątku, podpisanej w Wiedniu dnia 13 stycznia 2004 r7.

${ }^{2}$ W. Bartoszewski, Austriacy sa wygodni, „Gazeta Wyborcza” 2001, nr 1431, s. 7.

3 A. Stadler, Zapomniany przyjaciel, "Sprawy Międzynarodowe” 1997, nr 5, s. 19-27.

${ }^{4}$ M. Zając, Wszyscy bezpieczni, Wasza Wysokość!, „Tygodnik Powszechny” 2004, nr 18.07, s. 13.

${ }^{5}$ Inicjatywy kulturalne polsko-austriackie w pracy E. Nowak, Polska młodzież $w$ Austrii w XIX/XXw. Lublin 2007, A. Uznański, Interesy z Austria, „Europa” 1998, nr 4, s. 39-41, K.K. Kuczyński, Od Gerharta Hauptmanna do Otto Forst de Battaglii. W kręgu literatury i historii Austrii i Niemiec XX wieku, Płock 2006.

${ }^{6}$ A. Kisztelińska-Węgrzyńska, Traktaty polsko-austriackie z lat 1955-1989, Łódź 2011.

7 Protokół obowiązuje od dnia 10 października 2008 r. i ma zastosowanie: - w odniesieniu do podatków potrącanych u źródła - w stosunku do dochodu uzyskanego od dnia 1 stycznia 2009 r. - w odniesieniu do pozostałych podatków od dochodu oraz podatków od majątku (dywidendy, odsetki, należności licencyjne, zyski z przeniesienia własności majątku), w stosunku do podatków należnych za każdy rok podatkowy rozpoczynający się w dniu 1 stycznia 2009 r. lub po tym dniu. Należy dodać, że postanowienia Protokołu odnoszą się do tych polskich obywateli, którzy są rezydentami podatkowymi w Polsce. Protokół zmienia dotychczas obowiązującą metodę unikania podwójnego opodatkowa- 
W wyniku dyskusji jaka wiązała się z wykonywaniem umowy doszło do jej uzupełnienia. Podpisano dodatkowy Protokół między RP a Republiką Austrii ws. unikania podwójnego opodatkowania, wszedł on w życie 10 X 2008 roku $^{8}$. Dwustronne umowy to nie tylko baza prawna wzajemnych stosunków polsko-austriackich, lecz również dziedzictwo pewnej tradycji tychże stosunków pozostawione jeszcze przez poprzedni ustrój ${ }^{9}$.

Wśród celów polityki zagranicznej Polski, jakie wyznaczył po 2004 roku MSZ wymienić można chociażby: czynne uczestnictwo w pracach instytucji europejskich na rzecz pogłębiania integracji UE; utrwalanie sojuszu politycznego ze Stanami Zjednoczonymi, a po przez to czynny udział w strukturach i misjach NATO; prace nad „partnerstwem wschodnim”, jako koncepcją współpracy z państwami Europy Środkowo-Wschodniej i Azji i wzmacnianie mniejszych obszarów współpracy strategicznej, jak chociażby Grupa Wyszehradzka ${ }^{10}$.

Ważnym obecnie instrumentem działań MSZ jest tzw. polityka publiczna, najbardziej widoczna w sferze kulturalnej i społecznej. Prowadzona wielokierunkowo dyplomacja publiczna realizowana przez MSZ RP obejmuje szerokie spektrum działań o charakterze informacyjnym, stawiających sobie za cel kształtowanie przychylnej Polsce zagranicznej opinii publicznej, poprawę i obiektywizację wiedzy i zrozumienia naszego kraju, jego historii, wkładu Polski i Polaków w rozwój Europy i świata, wzmocnienie prestiżu naszego kraju na arenie międzynarodowej, stymulowanie kontaktów i współpracy pomiędzy zagranicznymi i polskimi partnerami. Istotnym zadaniem jest także wzmocnienie wizerunku naszego kraju jako ważnego państwa w Europie, promotora europejskiej polityki wschodniej, mocnego ogniwa Sojuszu Północnoatlantyckiego, kraju cywilizacyjnego sukcesu, którego obywatele cenią sobie wolność i umieją się nią dzielić, kraju udzielającego coraz większej pomocy rozwojowej, wspierającego swoją diasporę, kraju bezpiecznego, posiadającego stabilne

nia tj. tzw. metodę proporcjonalnego zaliczenia na metodę wyłączenia z progresją. Dane za Wydziałem Promocji Handlu i Inwestycji Ambasady RP w Wiedniu http://www.wien. trade.gov.pl/pl/Guide/article/detail,2387,Podwojne_opodatkowanie_w_relacjach_Austria-Polska (11.12.2012).

${ }^{8}$ E. Matyszewska, Austriacki podatnik rozlicza się elektronicznie: zakładanie firmy w krajach wspólnoty, „Gazeta Prawna” 2007, nr 214, s. A16,Teksty umów, http://www.traktaty.msz. gov.pl/SearchTreaties.aspx?t=DW (18.11.2012), E. Stobiecka, Austria szykuje się do otwarcia rynku, „Dziennik Gazeta Prawna” 2010, nr 211, s. C9.

9 Departament Prawno Traktatowy MSZ, http://www.traktaty.msz.gov.pl/SearchTreaties.aspx?t=DW (18.11.2012).

${ }^{10}$ R. Sikorski, Informacja Ministra Spraw Zagranicznych nt. polityki zagranicznej RP w 2008 r., www.msz.gov.pl 18.11. 2012, Polityka Zagraniczna. Aktorzy, potencjały, strategie, pod red., T. Łoś - Nowak, Warszawa 2011, s. 283. 
perspektywy rozwoju dzięki przynależności do Unii Europejskiej i NATO, wartościowego partnera politycznego, gospodarczego, naukowego, społecznego i kulturalnego ${ }^{11}$.

Kiedy porównamy te priorytety z założeniami polityki zagranicznej Austrii to można stwierdzić, iż wzajemnie się uzupełniają. W świetle dokumentów publikowanych na stronie austriackiego MSZ rząd w Wiedniu opowiada się za: silną, socjalną i nowoczesną Europą, a co za tym idzie wspiera proces reform instytucji unijnych, optuje za rozbudową wspólnej europejskiej polityki zagranicznej i bezpieczeństwa, czy współpracy na rzecz pozyskiwania źródeł energii ${ }^{12}$. Z celów nie związanych bezpośrednio z integracją europejską wymienić można choćby działalność Austrii na forum ONZ, czy wsparcia dla obszarów słabiej rozwiniętych ${ }^{13}$. Warto zaznaczyć, że poza tym, że istnieje zgodność celów najistotniejszych, nie ma różnicy zdań w działaniach pośrednich. Brak takich obszarów dyplomatycznych (poza samymi negocjacjami w kwestiach szczegółowych na forum UE), gdzie działania Polski i Austrii wykluczałyby się. Stwarza to poprawne warunki do współpracy dwustronnej.

Wymiernym znacznikiem stosunków dwustronnych na poziomie politycznym jest liczba wizyt przedstawicieli państwowych najwyższego szczebla. W wyniku przynależności obu krajów do UE doszło do intensyfikacji kontaktów przedstawicieli Polski i Austrii, na przykład w Radzie Europejskiej na szczeblu szefów państw i rządów, w Radzie na poziomie ministrów oraz w grupach roboczych Rady na poziomie eksperckim, w Parlamencie Europejskim spotykają się parlamentarzyści, w Komisji Europejskiej i sekretariacie Rady są urzędnicy o polskim i austriackim obywatelstwie, w Komitecie Regionów przedstawiciele regionów, w Komitecie Ekonomiczno-Społecznym przedstawiciele społeczeństwa obywatelskiego.

Wśród istotnych spotkań państwowych na najwyższym szczeblu, których ilość wzrastała systematycznie od 2002, a mających miejsce w latach 2004-2011, wymienić należy: wizytę prezydenta Aleksandra Kwaśniewskiego w Austrii w dniach 19-20 II 2004 r., rewizytę prezydenta Austrii Heinza Fischera w Polsce 10 XII 2004 roku., ponowną wizytę prezyden-

${ }^{11}$ Dokument na stronie MSZ http://wieden.msz.gov.pl/pl/wspolpraca_dwustronna/ dyplomacja_publiczna_i_kulturalna (11.12.2012).

12 A. Langle, Austriacka polityka europejska i zagraniczna ze szczególnym uwzględnieniem wspótpracy między Polska a Austria, "Acta Universitatis Wratislaviensis. Przegląd Prawa i Administracji", 2007, s. 146.

${ }^{13}$ Bilateralne stosunki między Austrią a Polską osiągnęły nową jakość w wyniku wspólnej przynależności do UE, do której Austria przystąpiła 1 stycznia 1995 roku, na co dwie trzecie ludności wyraziło zgodę podczas referendum. Polska natomiast przystąpiła do Unii 1 maja 2004 r., po wyrażeniu zgody w referendum przez 77\% ludności. 
ta Aleksandra Kwaśniewskiego 2 XII 2005 roku i wizytę ministra spraw zagranicznych Stefana Mellera w Wiedniu 20-21 I 2006 roku. W następnym roku Alfred Gusenbauer, kanclerz federalny, spotkał się z premierem Jarosławem Kaczyńskim i Marszałkiem Sejmu Ludwikiem Dornem przy okazji konferencji „Przyszłość europejskiej lewicy” (Warszawa, 11 i 12 czerwca). W roku 2008 dwukrotnie odwiedzał Austrię prezydent Lech Kaczyński, ponadto na zaproszenie minister spraw zagranicznych Ursuli Plassnik przybył do Wiednia w II 2008 roku szef polskiego MSZ Radosław Sikorski. W 2009 roku przebywał z wizytą w Wiedniu wicepremier Waldemar Pawlak, w tym samym czasie przebywał w Polsce Prezydent Heinz Fischer. W 2010 roku odbyło się szereg spotkań na niższym szczeblu, wśród nich wymienić można choćby przyjazd wiceburmistrz Wiednia Renate Brauner na zaproszenie prezydent Warszawy Hanny Gronkiewicz-Waltz. W 2011 roku z wizytą do Wiednia udali się premier Donald Tusk (maj) i prezydent Bronisław Komorowski (lipiec). Trzeba zaznaczyć że częstotliwość wizyt państwowych była wielokrotnie wyższa od tych notowanych przed przystąpieniem Polski do UE. Dominuje również większa ilość wyjazdów polskich dyplomatów i polityków do Austrii, niż austriackich do Polski ${ }^{14}$.

Również współpraca regionalna jest coraz intensywniejsza, zarówno na płaszczyźnie państwowej w ramach Partnerstwa Regionalnego, zrzeszającego Austrię, Polskę, Czechy, Słowację, Węgry, Słowenię, jak i na płaszczyźnie regionów ${ }^{15}$. I tak austriacki land Styria zawarł umowę o współpracy z siedmioma województwami, między innymi z dolnośląskim; Wiedeń ma swoje przedstawicielstwo w Krakowie, Dolna Austria w Warszawie, Górna Austria współpracuje m.in., ze Śląskiem w ramach projektu z zakresu rynku pracy. Ponadto istnieją partnerstwa miast i gmin, np. Innsbrucka i Krakowa, a także współpraca między takimi związkami miast i gmin, m.in., w ramach International Communal Network (ICNW). Głównymi punktami ciężkości są również tutaj współpraca w ramach Unii Europejskiej oraz wspólne projekty, które w dużej części są współfinansowane ze środków unijnych ${ }^{16}$.

W obecnej sytuacji ekonomicznej niezwykle istotne znaczenie dla relacji dwustronnych mają wskaźniki dotyczące wymiany handlowej. Na wstępie należy zaznaczyć, że Austria należy do grona największych inwestorów zagranicznych w Polsce, szczególnie w dziedzinie bankowości

${ }^{14}$ Wybór wizyt dwustronnych podany za Ambasada Austriacka w Warszawie, http://www. bmeia.gv.at/pl/ambasada/warszawa/stosunki-bilateralne/wizyty-bilateralne.html 18. 11. 2012.

${ }^{15}$ Na temat aktualnej wspótpracy regionalnej Polski i Austrii w http://wieden.msz.gov.pl/ pl/wspolpraca_dwustronna/polsko_austriacka_wspolpraca_regionalna (11.12.2012).

16 A. Langle, op. cit., s. 152. 
i ubezpieczeń, w przemyśle budowlanym, opakowań, papieru i przemysłu spożywczego. Od przełomu w 1989 r. austriackie firmy zainwestowały w Polsce około 3 miliardów euro i stworzyły jednocześnie wiele miejsc pracy. Gospodarka Austrii profituje przede wszystkim z członkostwa w UE i jej rozszerzenia. Eksport pozostaje w dalszym ciągu głównym motorem austriackiej gospodarki i tempo jego wzrostu nadal jest b. wysokie. Co trzecie miejsce pracy w gospodarce narodowej uzależnione jest od produkcji towarów lub świadczenia usług przeznaczonych na rynki zagraniczne ${ }^{17}$. Udział Austrii w handlu światowym, na przestrzeni ostatnich lat, wynosi ok. 1,0\%. Główni partnerzy Austrii po stronie eksportu to RFN, Włochy i USA, a po stronie importu RFN, Włochy i Chiny ${ }^{18}$.

Traktat Akcesyjny ze Wspólnotami Europejskimi i ich krajami członkowskimi, który wszedł w życie w dniu 1.05.2004 r. posiada podstawowe znaczenie dla całokształtu współpracy gospodarczej i wymiany handlowej między Polską a krajami Unii Europejskiej, w tym z Austrią. Obroty handlu zagranicznego liczone w cenach bieżących wzrosły w latach 20002005 o 1 mld 600 mln zł, Natomiast w latach 2005-2010 o kolejne 4 mld zł. W 2005 roku po raz pierwszy odnotowano dodatnie saldo handlowe, które Polska utrzymała nawet w dobie kryzysu światowego ${ }^{19}$. Szczególnie wysoką dynamikę wzrostu eksportu do Austrii odnotował po raz kolejny sektor rolno-spożywczy $(+30 \%)$, a wolumen tego eksportu podwoił się w ostatnich trzech latach. W strukturze towarowej eksportu artykuły rolno-spożywcze zwiększyły dzięki temu swój udział do prawie $12 \%$, ale dominują w niej przemysłowe wyroby przetworzone (53\% całości ekspor$\mathrm{tu})$, wyroby metalurgiczne $(19 \%)$ oraz produkty mineralne $(16 \%)^{20}$.

Polska wzmocniła w 2007 roku swoje 3. miejsce wśród partnerów handlowych Austrii w EŚW (po Węgrzech, Czechach). Udział natomiast Austrii $\mathrm{w}$ globalnych obrotach towarowych Polski ze światem wynosi obecnie 1,8\%, a w obrotach z krajami rozszerzonej UE 2,5\%. Wśród wszystkich partnerów handlowych Austrii, Polska zajęła w ubr. 10. miejsce w eksporcie i 15. w imporcie. Austria natomiast utrzymuje od kilku lat pozycje 12-13 partnera handlowego Polski. W Polsce reprezentowanych jest prawie 800 firm austriackich. Skumulowana wartość inwestycji bezpośrednich Austrii w Polsce na koniec 2009 roku wyniosła wg danych NBP

17 Biuletyn Gospodarczy Ambasady RP w Wiedniu 2011, nr 1, http://wieden.msz.gov.pl/ pl/wspolpraca_dwustronna/biuletyn_gospodarczy/2011 (11.12.2012).

${ }_{18}$ Wskaźniki makroekonomiczne Austrii na stronie Ambasady RP w Wiedniu http:// wieden.msz.gov.pl/pl/wspolpraca_dwustronna/wskazniki_makroekonomiczne_austrii (11.12.2012).

${ }^{19}$ Rocznik Statystyczny Rzeczpospolitej Polskiej 2011, Warszawa 2011, s. 548.

${ }^{20}$ Austria-Twój partner w Unii Europejskiej, „Informator Rynkowy Dla Polskiego Przedsiębiorcy" 2004, nr 5, s. 14. 
3,47 mld EUR. Stanowi to 3,7\% ogółu dużych zagranicznych inwestycji bezpośrednich w Polsce i daje Austrii 10 miejsce wśród zagranicznych inwestorów. W 2007 r. austriaccy inwestorzy zainwestowali ok. 400 mln EUR, głównie w sektorze nieruchomości i przemyśle materiałów budowlanych. W Polsce prowadzi działalność 39 austriackich firm, które zainwestowały minimum $1 \mathrm{mln}$ USD. W negocjacjach akcesyjnych Austria uzyskała prawo do zastosowania do 2011 roku czasowych ograniczeń w dostępie do rynku pracy i usług. Okres przejściowy (wg modelu 2 lata +3 lata + ewentualnie 2 lata) oznacza, że legalna praca w Austrii możliwa jest tylko w oparciu o pozwolenie na pracę. Ograniczenia w dostępie do rynku pracy obejmują także świadczenie przez polskie firmy niektórych usług oddelegowanymi pracownikami z Polski. Usługi wrażliwe, czyli objęte ograniczeniami to ogrodnictwo, cięcie, rzeźbienie i wykańczanie kamienia, montaż elementów z metalu i części tych elementów, usługi budowlane, ochroniarskie, sprzątanie i czyszczenie obiektów, opieka w domu nad chorymi, prace o charakterze socjalnym. Ograniczenia te nie dotyczą usług realizowanych samodzielnie przez jednoosobowe firmy polskie ${ }^{21}$.

Na tle innych państw europejskich wskaźniki współpracy gospodarczej kształtują się korzystnie, lecz choć mają tendencję wzrostową Austrię można porównać do takich partnerów Polski jak Belgia, Dania i Hiszpania $^{22}$. Członkostwo Polski w Unii sprawia, że ten wzrastający rynek stał się bardziej interesujący dla austriackich przedsiębiorstw. Przykładem są tu między innymi dziesiątki tysięcy Polaków spędzających co roku w Austrii urlop, jak również rosnąca liczba obywateli austriackich odwiedzających Polskę w celach turystycznych. Według informacji Polskiej Organizacji Turystycznej w 2008 roku odwiedziło Polskę 354 tysiące Austriaków ${ }^{23}$. W kolejnych latach liczba ta wahała się. Według danych Instytutu Turystyki „do Polski przyjechało w 2010 roku 310 tys. Austriaków, co oznacza wzrost w stosunku do roku ubiegłego o ok. $11 \%$ i klasyfikuje Austrię na 9. miejscu wśród przyjazdów turystów zagranicznych do Polski. Osiągnięty poziom 3,9\% wyjazdów do Polski wśród 8-milionowego społeczeństwa austriackiego jest bardzo dobrym wynikiem, jednak potencjał tego rynku jest jeszcze nie w pełni wykorzystany" ${ }^{\prime 24}$. Najchętniej

${ }^{21}$ Szczegółowe dane dotyczące możliwości podjęcia pracy i rozpoczęcia działalności gospodarczej w Austrii podaje Ministerstwo Gospodarki w dokumencie Założenie działalności gospodarczej w Austrii http://www.eu-go.gov.pl/pl/dla-przedsiebiorcy/rozpoczynamdzialalnosc-gospodarcza/rozpoczynam-dziaalno-gospodarcz-w-ue/220-zakadanie-dziaalnoci-gospodarczej-w-austrii/ (11.12.2012).

${ }_{22}$ Rocznik Statystyczny Rzeczpospolitej 2011, Warszawa 2011, s. 548.

23 A. Langle, op. cit., s. 153.

${ }^{24}$ Austriaccy turyści coraz częściej odwiedzają Polskę, Polsko-Austriacka Inicjatywa Wspótpracy Gospodarczej, http://www.paiwg.org/article/austriaccy-turysci-coraz-czesciej-wybieraja-polske (11.12.2012). 
wyjeżdżająca grupą wiekową jest 35-45 lat, w wyjazdach do Polski dominuje grupa wiekowa 50+. W 2010 roku przeciętny Austriak wydał w Polsce ok. 495 USD, czyli o 105 USD więcej niż wynosi średnia, oraz na osobodzień 83 USD, czyli o 8 USD więcej niż przeciętny turysta zagraniczny. Największym powodzeniem na tutejszym rynku cieszą się oferty wyjazdów do miast, szczególnie Krakowa, Warszawy, Gdańska, Łodzi, Wrocławia, Przemyśla, Częstochowy. Z regionów Małopolska, Warmia i Mazury, Podlasie, Podkarpackie i coraz częściej wyjazdy nad morze. Najchętniej Austriacy przyjeżdżają do nas w II i III kwartale. Od kilku lat rośnie również ilość zapytań o naszą ofertę zimową, pomimo, że Austria jest w tej dziedzinie światową potęgą, urlopy na nartach są $u$ nas jeszcze cenowo atrakcyjne.

Wśród obszarów gospodarczych, którymi Austriacy są szczególnie w Polsce zainteresowani wymienić należy bankowość, budownictwo i przemysł chemiczny. Jeśli idzie o działalność bankową Austrii na rynkach wschodnich w ostatnich latach to należy wspomnieć o aktywności UniCredit Group w obszarze Środkowej i Wschodniej Europy prowadzoną przez Bank Austria. Z przedstawionego przez Zarząd Banku planu prac na nadchodzące 5 lat wynika, że będzie on kontynuował działania mające na celu zwiększenie udziału na rynkach EŚW i Rosji ${ }^{25}$. Austriacki bank Raiffeisen Bank International (RBI) został właścicielem większościowego pakietu udziałów w Polbanku, które na sprzedaż wystawił grecki EFG Eurobank Ergasias. Do grupy zainteresowanych zakupem oprócz RBI należeli włoski Bank Intesa Sanpaolo oraz francuski PNB Paribas. Zakup 70\% udziałów skoncentrowanego głównie na obsłudze klientów indywidualnych Polbanku umożliwi RBI rozszerzenie palety usług i wzmocnienie pozycji banku w Polsce. Dotychczas, utworzony w 1991 r. Raiffeisen Bank Polska SA, skupiał się w szczególności na obsłudze przedsiębiorstw.

Austria i Niemcy jako ostatnie państwa UE 1 maja 2011 otworzyły swoje rynki pracy dla obywateli nowych państw członkowskich. W ramach działań przygotowawczych Austria przedstawiła projekt ustawy dot. zwalczania dumpingu płacowego i dumpingu społecznego, która przewiduje m.in. kontrolę wypłacania minimalnego wynagrodzenia oraz nakładania kar w przypadku wykroczeńn ${ }^{26}$. Najistotniejsze kwestie poruszone $\mathrm{w}$ projekcie ustawy dot. minimalnego wynagrodzenia, które - w przypadku delegowania pracowników - zobowiązują zagranicznego przedsiębiorcę do przestrzegania warunków pracy i wynagrodzenia obowiązujących w Austrii. W myśl projektu ustawy zagraniczni praco-

${ }_{25}$ Biuletyn Gospodarczy Ambasady RP w Wiedniu 1/2011, http://wieden.msz.gov.pl/pl/ wspolpraca_dwustronna/biuletyn_gospodarczy/2011 (11.12.2012).

${ }_{26}^{26}$ Komunikat Ministerstwa Pracy i Polityki Społecznej na stronie http://www.mpips.gov. pl/praca/praca-za-granica/austria/ (11.12.2012). 
dawcy na czas zatrudnienia pracowników w Austrii będą zobowiązani do przygotowania wszystkich dokumentów dot. wynagrodzenia w języku niemieckim i przedkładania ich na prośbę organów kontrolnych. W wypadku wykroczeń związanych z ww. przepisami projekt ustawy przewiduje objęcie zagranicznego pracodawcę zakazem świadczenia usług na terenie Austrii przez okres min. 12 miesięcy. Złamanie tego zakazu grozi grzywną w wys. 500-5.000 euro. W przypadku nieprzestrzegania przepisów dot. minimalnego wynagrodzenia pracodawca może zostać ukarany grzywną w wys. 5.000-100.000 euro, natomiast uniemożliwienie dostępu organom kontrolnym do zakładu pracy karane będzie grzywną w wys. 5.000-50.000 euro. Projekt ustawy był tematem dyskusji rady ministrów w lutym 2010., natomiast wprowadzenie ustawy nastąpiło 01.05.201127.

Niezwykle istotnym elementem działań dyplomatycznych staje się we współczesnym świecie oddziaływanie kulturowe i społeczne. $Z$ dokumentów publikowanych na stronie Ministerstwa Spraw Zagranicznych wynika iż „dyplomacja publiczna prowadzona przez Ministerstwo Spraw Zagranicznych RP to zestaw działań o charakterze strategicznym, koncepcyjnym, analitycznym, koordynacyjnym i wykonawczym, które poprzez kształtowanie postaw społecznych i opinii publicznej za granicą wpływają na realizację istotnych interesów Polski w świecie, używając narzędzi i metod spoza obszaru tradycyjnej dyplomacji jako obszaru relacji międzypaństwowych. Celem nadrzędnym dyplomacji publicznej jest uzyskiwanie za granicą zrozumienia i poparcia dla polskiej racji stanu i polityki władz RP. Stanowiąc uzupełnienie dla tradycyjnej dyplomacji, jest działalnością skierowaną do zagranicznych instytucji, organizacji i społeczeństw"28.

W Polsce uważanej za kulturowego sąsiada, Austria jest reprezentowana przez austriackie fora kultury w Warszawie i Krakowie, Opolu, Przemyślu, Poznaniu i Wrocławiu. W ramach promocji wiedzy na temat kultury polskiej przed przystąpieniem naszego kraju do UE zorganizowano szereg uroczystości pod wspólnym hasłem Rok Polski w Austrii. Odbył się on na przełomie 2002-2003 roku w wyniku porozumienia zawartego między Ministrami Spraw Zagranicznych Polski i Austrii. Realizowany był głównie przez Instytut Adama Mickiewicza we współpracy z Instytutem Polskim w Wiedniu, Ambasadą Polską w Wiedniu, Muzeum Narodowym w Warszawie, Zamkiem Królewskim w Warszawie. Projekt był częścią rządowego „Ramowego programu promocji zagranicznej akcesji Polski do Unii Europejskiej"29. Patronat honorowy nad Rokiem Polskim w Austrii objęli Prezydent Republiki Austrii Thomas Klestil i Prezydent

${ }^{27}$ Działalność gospodarcza w Austrii, http://wieden.msz.gov.pl/pl (11.12.2012).

${ }^{28}$ Dokument DPPK MSZ na stronie http://wieden.msz.gov.pl/pl/wspolpraca_dwustronna/dyplomacja_publiczna_i_kulturalna (11.12.2012).

${ }^{29}$ Rok Polski w Austrii, http://mikroorchestra.com/press/austria.pdf (11.12.2012). 
Rzeczpospolitej Polskiej Aleksander Kwaśniewski. Była to największa promocja polskiej kultury za granicą w 2002 roku, obejmowała ponad 120 wydarzeń kulturalnych prezentowanych $\mathrm{w}$ muzeach, galeriach, salach koncertowych Wiednia, Linzu, Grazu, Salzburga i Innsbrucku.

Zainteresowaniem cieszyły się spotkania z polskimi pisarzami w Wiedniu, Linzu, Salzburgu i kilku innych miastach. Wszystkie wieczory autorskie odbywały się przy pełnych salach. W sumie wzięło w nich udział około 2 tys. osób. Z austriackimi czytelnikami spotkali się m.in. Ewa Lipska, Adam Zagajewski, Paweł Huelle, Ewa Kuryluk, Andrzej Stasiuk, Michał Głowiński, Piotr Sommer, Olga Tokarczuk, Krzysztof Varga, Daniel Odija oraz Hanna Krall. „Literatur und Kritik” zamieściło teksty Krzysztofa Vargi, Andrzeja Stasiuka, Ryszarda Kapuścińskiego oraz teksty tłumacza i slawisty Martina Pollaka. W programie muzycznym najbardziej interesujące dla Austriaków okazały się koncerty jazzowe. Wysłuchało ich prawie 4 tys. osób. Na JazzFestWien i w popularnym klubie Porgy\&Bess zagrali m.in. Urszula Dudziak, Zbigniew Namysłowski, Kuba Stankiewicz, Tomasz Stańko. Stańko uhonorowany został Europejską Nagrodą Jazzową im. Hansa Kohlera, którą po raz pierwszy wręczono w tej kategorii ${ }^{30}$.

Wyrazem ścisłych kontaktów między naszymi krajami jest Polsko-Austriacka Nagroda. Została ufundowana w 2001 r. przez ministrów spraw zagranicznych Polski i Austrii jako polsko-austriacka nagroda dziennikarska, a następnie w roku 2005, przekształcona w Nagrodę na Rzecz Rozwoju Stosunków Polsko-Austriackich ${ }^{31}$. Jej celem jest pogłębianie wzajemnego zrozumienia i współpracy między Polską i Austrią. Nagroda jest przyznawana raz w roku zamiennie - to polskim to austriacki dziennikarzom, przedstawicielom świata kultury, naukowcom i innym osobom z Polski i Austrii, które swoją działalnością wspierają stosunki między naszymi krajami. O przyznaniu nagrody decyduje jury, w którego skład wchodzą ambasadorowie RP w Austrii w Polsce oraz znane polskie i austriackie osobistości ze świata mediów, kultury, gospodarki i nauki ${ }^{32}$.

${ }^{30}$ Przebieg Roku Polskiego w Austrii http://www.wspolnota-polska.org.pl/index222d. html?id=kw1_2_13 (11.12.2012).

${ }^{31}$ Sposób przyznawania wyróżnienia i laureaci na stronie Ambasady Republiki Austrii w Warszawie http://www.bmeia.gv.at/pl/ambasada/warszawa/aktualnosci/informacje-prasowe-z-2011-roku/polsko-austriacka-nagroda-dla-martina-pollacka.html (11.12.2012).

${ }^{32}$ Laureatem w 2011 roku był Martin Pollack Nagrodę w wysokości 5000 Euro wręczyli podsekretarz stanu w polskim MSZ, Rafał Wiśniewski, oraz Ambasador Republiki Austrii Polsce, dr Alfred Längle. Laudację wygłosił Jacek Buras, długoletni dyrektor Polskiego Instytutu w Wiedniu i tłumacz literatury austriackiej. http://www.bmeia.gv.at/pl/ ambasada/warszawa/aktualnosci/informacje-prasowe-z-2011-roku/polsko-austriacka-nagroda-dla-martina-pollacka.html (11.12.2012). 
Niezwykle istotnym ośrodkiem wymiany naukowej i kulturalnej jest wiedeński oddział Polskiej Akademii Nauk. Od 1991 roku przeprowadzano konferencje, sympozja, wykłady, wystawy, odczyty, prezentacje książek, dyskusje, i wiele innych imprez kulturalnych w łącznej liczbie kilku tysięcy. Obecnie, co roku odbywa się ponad 50 wykładów i paneli dyskusyjnych w ramach różnorodnych cykli wydarzeń naukowych. Do stałych przedsięwzięć zaliczyć można choćby: Forum Dyskusyjne im. Konrada Celtisa, Wykłady Kopernikańskie, Wykłady Stypendystów Fundacji Lanckorońskich. Stacja PAN publikuje regularnie materiały naukowe jak choćby Rocznik, czy Symposia i Seminaria ${ }^{33}$.

Do grona instytucji wspierających polską kulturę i naukę w Austrii zaliczyć należy również Instytut Polski w Wiedniu. Prezentuje on mieszkańcom Austrii polską kulturę, historię, naukę i wiedzę o współczesnej Polsce oraz polskim społeczeństwie, a ponadto działa na rzecz wzmocnienia współpracy pomiędzy polskimi i austriackimi instytucjami kulturalnymi, środowiskami opiniotwórczymi i artystami. Instytut Polski jest instytucją non-profit, podlegającą Ministerstwu Spraw Zagranicznych Rzeczypospolitej Polskiej i należy do sieci 21 Instytutów Polskich na świecie $^{34}$. Ponadto $\mathrm{w}$ wyniku realizacji umowy o wymianie kulturalnej i naukowej z 1967 roku, nadal rozwija się wymiana na poziomie uczelni wyższych. Lektorzy austriaccy pracują na uniwersytetach w Toruniu, Krakowie, Łodzi, Poznaniu, Warszawie i Wrocławiu. Także kulturalna i naukowa wymiana między naszymi krajami stała się dużo intensywniejsza dzięki przynależności naszych krajów do Unii Europejskiej.

Wśród mniejszych inicjatyw kulturalnych łączących narody polski i austriacki wymienić można choćby odsłonięcie pomnika Fryderyka Chopina w Wiedniu w 2010 roku czy Hietzingerabend Salon. Jest to cykliczna impreza organizowaną przez Ambasadę RP w Wiedniu, gromadzącą szczególną publiczność, zainteresowaną ekskluzywnymi wykładami i rozmowami z uznanymi osobistościami świata polityki czy gospodarki, ale także ceniącą kontakt z kulturą i sztuką, ponieważ Hietzingerabend Salon to także wspaniałe koncerty cenionych artystów ${ }^{35}$.

Wśród inicjatyw kulturalnych, które wyróżniają się na tle działań popularyzujących wymianę austriacko-polską należy wymienić działalność

33 Strona internetowa wiedeńskiego oddziału PAN http://www.viennapan.org/index.php/ pl/publikacje/symposien-und-seminare-2 (11.12.2012).

${ }^{34}$ Oficjalna strona Internetowa Instytutu http://www.polnisches-institut.at/2,1,78,pl (11.12.2012).

35 Z okazji Międzynarodowego Roku Chopinowskiego 2010 miasto Wiedeń otrzymało od Rządu RP niecodzienny prezent - pomnik Fryderyka Chopina. Pomnik upamiętnia dwukrotny, łącznie dziewięciomiesięczny pobyt kompozytora w Wiedniu w latach 1829-1831. 
Forum Kultury Austriackiej w Warszawie. Celem działań ostatnich lat jest zacieśnienie współpracy z polskimi instytucjami partnerskimi spoza stolicy, tak, aby także na tzw. prowincji mogły dojść do głosu siły twórcze. Blisko 200 imprez kulturalnych rocznie odbywa się właśnie poza Warszawą.

W pomieszczeniach Austriackiego Forum Kultury w Warszawie znajduje się, powiększona w 2002, Galeria Austriacka, która stała się otwartym miejscem spotkań polskiej i austriackiej sztuki współczesnej. Od roku 2000 regularnie odbywają się koncerty z cyklu "Muzyczne forum młodych", które poświęcone są austriackiej muzyce współczesnej. Od 2005 roku istnieje biblioteka dziecięca, która przeznaczona jest dla najmłodszej publiczności. W małej sali imprezowej wisi od 2007 roku wystawa prac Zygmunta Januszewskiego. Dzięki programowi "Artist-in-residence”, tworzonym wspólnie z landem Salzburg i miastem Wiedniem, trójka artystek i artystów czy pisarek i pisarzy rocznie może korzystać z miesięcznego pobytu rezydencyjnego w Warszawie, by na koniec zaprezentować swoje prace ${ }^{36}$.

Podsumowując należy podkreślić, iż u podstaw najnowszych stosunków polsko-austriackich legły wspólne cele polityki zagranicznej wyznaczone przez państwa współdziałające na forum Unii Europejskiej. Austria zajmuje istotne miejsce $\mathrm{w}$ gronie państw europejskich $\mathrm{z}$ którymi Polska utrzymuje poprawne, oparte na zasadzie wzajemnych korzyści relacje gospodarcze. Tendencja do zacieśnienia tychże kontaktów widoczna w danych statystycznych pozytywnie rokuje w najbliższej przyszłości. Stałym i ważnym elementem poprawnej współpracy jest bogata i barwna wymiana na poziomie kultury i nauki, z której owoców korzystają obydwa narody. Jest to nie tylko ważny element wymiany dyplomatycznej pomiędzy Polską i Austrią, ale coraz dostępniejszy i widoczny dzięki współczesnym mediom warunek porozumienia społecznego. W wywiadzie dla Tygodnika Powszechnego Erhard Busek przyznał, że zapytał kiedyś Aleksandra Gieysztora jak zdefiniować Europę Środkową. Wybitny polski historyk odparł: „,Europa Środkowa jest wszędzie tam, gdzie imiona Kacpra, Melchiora i Baltazara widnieją na framugach drzwi, gdzie ludzie śpią na łóżkach z desek, gdzie kobiecie wręcza się nieprawdopodobne ilości róż". Literatura polska, czeska czy węgierska może być w związku z tym bliższa wielu Austriakom niż niemieckojęzyczne dzieła Theodora Storma ${ }^{37}$.

Dostępność szeroko pojętych dóbr kultury, coraz szersze grono korzystające $\mathrm{z}$ tego dorobku, wyższy poziom życia i chęć poprawy warunków społecznych chociażby po przez większy udział w kulturze koresponduje z wielowątkowymi działaniami dyplomatycznymi Polski, pełnoprawne-

${ }^{36}$ Oficjalna Strona Internetowa Forum Kultury Austriackiej w Warszawie, http:// www.austria.org.pl/NEW/PL/onas.php (18.11.2012).

37 E. Busek, Między Zachodem a Użogrodem, „Tygodnik Powszechny” 2004, nr 18.07, s. 15. 
go uczestnika wspólnoty europejskiej. Relacje dwustronne znacznie mniej istotne $\mathrm{w}$ postępującym procesie globalizacji, niż zjawiska integracyjne stanowią uzupełnienie działań dyplomatycznych młodych demokracji do jakich zaliczyć należy Polskę. Austria stale zajmuje ważne miejsce w polskiej polityce zagranicznej korzystając z dotychczas wypracowanych narzędzi tworzenia poprawnych relacji.

\section{Zusammenfassung}

Die polnisch-österreichischen Beziehungen nach dem Ende des Zweiten Weltkrieges entwickelten sich in der Atmosphäre von gegenseitigem Interesse und politischer Unterstützung. Obwohl die Volksrepublik Polen und die Republik Österreich während des Kalten Krieges auf gegenüberliegenden Seiten des Eisernen Vorhangs standen, bemühten sie sich seit dem Jahr 1945 um die gegenseitige Anerkennung und die Möglichkeit der Handel Zusammenarbeit. In der ersten Etappe der polnisch-österreichischen Kooperation nach 1945 ist es sehr selten zu den Besuchen auf dem höchsten Niveau gekommen. „Abweichungen" unter den westlichen Staaten, die eine Chance für den wirtschaftlichen und politischen Austausch geben würden, so notwendig für die junge Volksdemokratie. In den Archiven des Ministeriums für Auswärtige Angelegenheiten sind Materialien zu finden, die detailliert die Vorbereitung und Durchführung des ersten österreichischen Besuchs auf höchster Ebene in Polen beschreiben. Im Dokument „Thesen für Gespräche”, das speziell für das Ministerium für Auswärtige Angelegenheiten im Februar 1960 vorbereitet wurde, lesen wir, dass die polnische Regierung nicht die Eventualität der Zusammenarbeit mit den West-Länder ausschloss (auch mit den NATO-Mitgliedern), und wollte sich richtig für so eine Zusammenarbeit vorbereiten. Gemäß den polnischen Diplomaten konnte die Republik Österreich dazu helfen, die politische Isolation, in der sich die Volksrepublik befand, zu brechen. 